\title{
Teams Games Tournament (TGT) Sebagai Metode dalam Peningkatan Motivasi dan Prestasi Belajar Matematika Siswa
}

\begin{abstract}
Maftuhin
Email: h.maftuhin31121963@gmail.com

SMA Negeri 1 Selong

Received: November 2020

Accepted: Juli 2021

Online Published: Juli 2021

Abstract

While the objectives of this study are: (a) Increase the motivation to learn Mathematics of SMA Negeri 1 Selong students through the Teams Games Tournament (TGT) type of cooperative learning model (b) Improve the mathematics learning achievement of SMA Negeri 1 Selong students through the Teams Games type cooperative learning model Tournament (TGT) (c) Describe students' responses to the implementation of the cooperative learning model with the Teams Games Tournament (TGT) type. In this study, there were (action research) of 3 cycles. Each cycle consists of several stages, namely: the planning stage, the action stage, and the observation and reflection stages. The subjects of this study were students of class XI IPS 1 semester I of the 2018/2019 academic year, the data obtained were in the form of formative test results and observation sheets of learning activities. Based on the research data, it was found that the average value of students' learning outcomes in the initial conditions in each cycle had increased. In cycle I the average value is 65.40, cycle II the average value is 68.00 and in cycle III the average value is 69.00. The conclusion obtained is that there is a significant increase in learning outcomes through the implementation of the cooperative learning model with the Teams Games Tournament (TGT) type.
\end{abstract}

Keywords: achievement, motivation, TGT media (Teams Games Tournament)

\begin{abstract}
Abstrak
Tujuan dari penelitian ini sendiri adalah: (a) Meningkatkan motivasi belajar Matematika siswa SMA Negeri 1 Selong melalui model pembelajaran kooperatif tipe Teams Games Tournament (TGT) (b) Meningkatkan prestasi belajar Matematika siswa SMA Negeri 1 Selong melalui model pembelajaran kooperatif tipe Teams Games Tournament (TGT) (c) Menjelaskan tanggapan siswa terhadap pelaksanaan model pembelajaran kooperatif dengan tipe Teams Games Tournament (TGT). Pada penelitian ini terdapat (action research) sebanyak 3 siklus. Setiap siklus terdiri dari beberapa tahap yaitu : tahapan perencanaan, tahapan tindakan (action), serta tahapan pengamatan dan refleksi. Subjek penelitian ini yaitu siswa kelas XI IPS 1 semester I Tahun Pelajaran 2018/2019, data yang diperoleh berupa hasil tes formatif dan lembar observasi kegiatan pembelajaran. Berdasarkan data hasil penelitian diperoleh rata-rata nilai hasil belajar peserta didik pada kondisi awal pada setiap siklus mengalami kenaikan. Pada siklus I nilai rata-rata diperoleh sebesar 65,40, siklus II nilai rata-rata sebesar 68,00 dan pada siklus III nilai rata-rata sebesar 69,00. Kesimpulan yang
\end{abstract}




\section{Educatio: Jurnal IImu Kependidikan}

Vol. 16, NNo 1 Jufi 2021, hal. 24-36

http://e-journal.hamzanwadi.ac.id/index.php/edc

e-ISSN: 2527-9998

DOI: 10.29408/edc.v16i1.2831

diperoleh adalah adanya peningkatan hasil belajar yang signifikan melalui pelaksanaan model pembelajaran kooperatif dengan tipe Teams Games Tournament (TGT).

Kata kunci: prestasi, motivasi, media TGT (Teams Games Tournament)

\section{PENDAHULUAN}

Matematika merupakan mata pelajaran yang kebanyakan kurang disukai siswa di sekolah. Hasil survey yang dilakukan peneliti menunjukkan jika ditanya mata pelajaran apa yang tidak disukai, maka hampir $75 \%$ menjawab matematika. Hal ini ditunjukkan oleh sebagian besar siswa yang tidak bersemangat ketika pelajaran Matematika berlangsung, rendahnya umpan balik dari siswa terhadap pertanyaan dan penjelasan guru, sebagian besar siswa di dalam kelas menjadi pasif dan tidak ada keberanian mengungkapkan apa yang sudah dan belum dipahami. Hal ini menyebabkan konsep-konsep yang dipahami oleh siswa apakah benar atau salah semakin sulit diketahui guru, meskipun guru telah berusaha menjelaskan materi dengan maksimal.

Untuk mengatasi rendahnya semangat para siswa dalam kegiatan pembelajaran matematika maka perlu adanya peningkatan motivasi dengan memberikan jenis pembelajaran yang bersifat Cooperative Learning yang lebih menarik dan lebih melibatkan siswa. Cooperatif Learning diungkap oleh Slavin (1980) yang menyatakan bahwa dimana dalam proses pembelajaran siswa dikelompokkan dalam kelompok-kelompok kecil dan memberika penghargaan berdasarkan kualitas dari setiap pekerjaannya. Dalam pembelajaran dengan menggunakan metode cooperatif learning terdapat beberapa tipe didalamnya, salah satunya adalah Teams Games Tournament (TGT). TGT merupakan salah satu tipe dari model pembelajaran yang menerapkan kegiatan kelompok dalam pembelajarannya yaitu kompetisi untuk menyampikan buah pikiran/ide berdasarkan hasil diskusi yang telah dilakukan (Erlinda, 2017). TGT memberikan konsep baru dalam memberikan kesempatan siswa untuk menekankan pada keaktifan dan inovasi yang dimiliki (Kholisho, 2017). Dengan suasana permainan dalam kegiatan belajar mengajar diharapkan dapat menimbulkan efek rekreaktif dalam kegiatan belajar siswa. Kegiatan pembelajaran yang dikolaborasikan dengan permainan dirancang dalam pembelajaran Cooperative Learning dengan tipe TGT yang sangat memungkinkan setiap siswa untuk dapat belajar lebih satai disamping menumbuhkan rasa tanggung jawab, kerjasama dan persaingan yang sehat.

Pada dasarnya pentingnya peserta didik/siswa memiliki kemampuan matematika sebab kemampuan matematika tersebut sebagai kemampuan dan keterampilan peserta didik kedepannya agar mampu memprediksi, mengekplor serta berfikir secara logis untuk memecahkan suatu masalah (Kuswanto, 2020). Berdasarkan paparan diatas, tujuan dalam penelitian ini adalah meningkatkan motivasi belajar, prestasi belajar matematika siswa SMA 
Educatio: Jurnal IImu Kependidikan

Vol. 16, No 1 Juli 2021, hal. 24-36

http://e-journal.hamzanwadi.ac.id/index.php/edc

e-ISSN: 2527-9998

DOI: 10.29408/edc.v16i1.2831

Negeri 1 Selong melalui pembelajaran kooperatif dengan tipe Teams Games Tournament (TGT).

\section{METODE PENELITIAN}

Metode yang digunakan dalam penelitian ini adalah penelitian tindakan kelas (PTK), diterapkan pada siswa kelas XI IPS 1 Semester ganjil mata pelajaran Matematika Wajib di SMA Negeri 1 Selong tahun pembelajaran 2018/2019. Subyek penelitian pada pada kelas XI IPS 1 berjumlah 36 siswa, terdiri dari 20 siswa laki-laki dan 16 siswa perempuan. Desain penelitian ini menggunakan model Kemmis dan Taggart dengan tahapan berupa perencanaan, tindakan, pengamatan, serta refleksi untuk setiap siklus (Ruswandi, 2010). Penelitian ini dilaksanakan melalui tiga siklus yang akan ditampilkan pada gambar berikut ini :

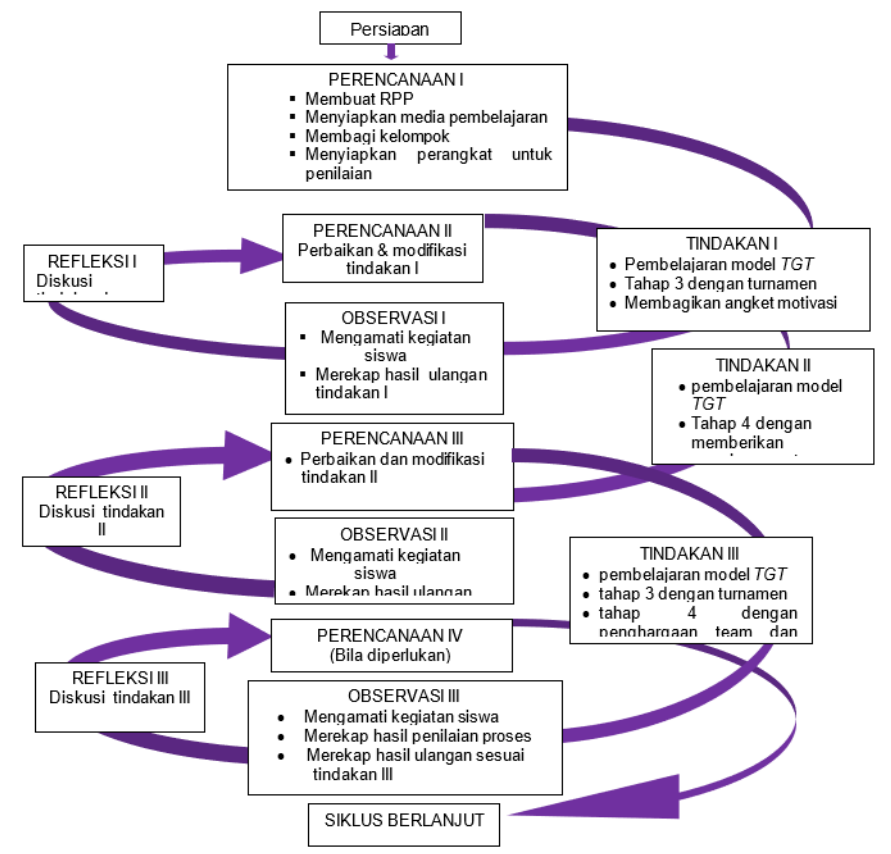

Gambar 1. Alur Pelaksanaan PTK

Proses pengamatan untuk melihat motivasi belajar matematika pada siswa kelas XI IPS 1 di SMA Negeri 1 Selong maka dilakukan observasi. Setelah dilakukan berbagai pengkajian reflektif dan diskusi terarah, maka ditetapkan tindakan untuk meningkatkan motivasi siswa dalam belajar matematika dengan menerapkan model pembelajaran kooperatif tipe Teams Games Tournament (TGT). Teknik pengumpulan data dalam penelitian ini adalah: dengan melakukan observasi (pengamatan), yaitu kegiatan untuk mengetahui situasi dan proses pelaksanaan kegiatan belajar mengajar yang berlangsung di dalam kelas, angket (kueisoner), untuk memperoleh data 


\section{Educatio: Jurnal IImu Kependidikan}

Vol. 16, NNo 1 Jufi 2021, hal. 24-36

http://e-journal.hamzanwadi.ac.id/index.php/edc

e-ISSN: 2527-9998

DOI: 10.29408/edc.v16i1.2831

motivasi belajar matematika siswa-siswi melalui model pembelajaran kooperatif tipe TGT, dan terakhir dilakukan tes, yaitu kegiatan untuk memperoleh data hasil belajar siswa setelah kegiatan pembelajaran dilakukan.

Penelitian tindakan kelas ini dilaksanakan dalam 3 siklus, yang tiap-tiap siklusnya mencakup tahapan berikut:

\section{Perencanaan (Planning)}

Perencanaan tindakan kelas meliputi penyusunan rencana pembelajaran, pembuatan skenario pembelajaran dengan teknik Teams Games Tournament (TGT), pembuatan media permainan sesuai dengan tema dalam rencana pembelajaran yang dilengkapi dengan petunjuk kegiatan dan aturan permainan, serta penyusunan alat-alat evaluasi tindakan. Penyusunan rencana pelaksanaan perbaikan pembelajaran (RPPP) dilakukan dengan memperbaiki dan menyesuaikan program pembelajaran yang telah dibuat. RPPP disusun sesuai dengan model Teams Games Tournament (TGT).

2. Tindakan (Acting)

Pelaksanaan tindakan meliputi beberapa hal yaitu:

a. Pembuatan kelompok-kelompok belajar yang terdiri dari maksimal empat orang siswa dengan kemampuan, ras, suku, jenis kelamin dan usia yang berbeda (heterogen).

b. Membagi petunjuk kegiatan atau aturan permainan yang telah dibuat pada tiap-tiap kelompok.

c. Siswa melaksanakan model pembelajaran tersebut sesuai dengan petunjuk kegiatan yang telah dibuat oleh guru mata pelajaran.

d. Masing-masing anggota kelompok berkompetisi untuk mendapatkan nilai tertinggi.

3. Pengamatan/Observasi (Observing)

Observasi pelaksanaan pembelajaran dilakukan secara kolaboratif yang mengacu pada instrumen monitoring yang telah direncanakan sebelumnya. Data tentang kondisi pembelajaran matematika diperoleh dari lembar observasi yang telah diisi observer (siswa). Data tingkat kemajuan motivasi belajar matematika pada siswa diperoleh dari lembar angket yang disebarkan setelah kegiatan pembelajaran pada setiap siklus berakhir. Sedangkan data hasil belajar siswa diperoleh dari hasil evaluasi berupa tugas dan ulangan harian.

4. Refleksi (Reflecting)

Kegiatan refleksi dilakukan berdasar pada hasil wawancara dengan siswa-siswa, hasil lembar pengamatan dan hasil diskusi dengan guru-guru. Hasil refleksi ini kemudian akan digunakan untuk menentukan langkah-langkah tindakan yang akan ditempuh selanjutnya.

\section{HASIL DAN PEMBAHASAN}

\section{Siklus 1}

Kegiatan pembelajaran siklus I dilaksanakan sebanyak 1 kali pertemuan dengan setiap pertemuan berlangsung selama 2 jam pelajaran ( 2 x 45 menit).

a. Perencanaan dan Persiapan Tindakan

Perencanaan dan persiapan tindakan yang dilakukan peneliti meliputi: 


\section{Educatio: Jurnal IImu Kependidikan}

Vol. 16, NNo 1 Jufi 2021, hal. 24-36

http://e-journal.hamzanwadi.ac.id/index.php/edc

e-ISSN: 2527-9998

DOI: 10.29408/edc.v16i1.2831

1) Penyusunan Rencana Pelaksanaan Pembelajaran (RPP) materi Pertidaksamaan Linear Dua Variabel.

2) Menyiapkan langkah-langkah pada model pembelajaran TGT

3) Menyiapkan lembar observasi pembelajaran

4) Menyiapkan LKS

5) Menyiapkan kartu soal untuk tournamen

6) Menyiapkan blangko nilai pada setiap meja kelompok dan blangko nilai kelompok.

b. Pelaksanaan Tindakan

Kegiatan pembelajaran pada siklus 1 ini dilaksanakan satu kali pertemuan dengan langkah-langkah yaitu:

1) Guru menjelaskan materi mengenai Dasar-dasar Pertidaksamaan

2) Siswa membentuk kelompok-kelompok belajar dan melakukan diskusi

3) Memulai permainan (game tournament)

4) Penghargaan kepada kelompok yang memperoleh nilai tertinggi

Pada tahap ini, kegiatan pembelajaran dimulai dengan menjelaskan materi mengenai Dasar-dasar Pertidaksamaan dengan metode demonstrasi dan tanya jawab antara guru dan siswa. Pada akhir penjelasan, guru makan emberikan kesempatan kepada siswa untuk mengajukan pertanyaan mengenai materi yang belum dipahami sebelum kegiatan diskusi kelompok dilangsungkan.

Setelah pemberian materi selesai dilakukan, siswa dikelompokan menjadi 10 (sepuluh) kelompok dengan masing-masing kelompok beranggotakan maksimal 4 (orang) siswa sesuai dengan format pembentukan kelompok pada Pra Kegiatan. Guru kemudian membagikan Lembar Kerja (LKS) berisi materi Dasar-dasar Pertidaksamaan untuk kemudian akan didiskusikan oleh setiap anggota kelompok.

Setelah diskusi kelompok selesai maka akan dilanjutkan dengan pertandingan (tournament) berdasarkan aturan berikut:

1) Setiap anggota kelompok akan mendapatkan penomoran 1, 2, 3, 4, yang dipasang di dada masing-masing siswa. Penomoran ini yang kemudian digunakan sebagai acuan untuk menentukan anggota tim tersebut akan bermain pada meja turnamen ke berapa. Misalnya pada kelompok Melati, salah satu anggota yang bernama Agus diberi nomor 1 oleh guru, ini berarti Agus akan bermain pada meja turnamen 1, begitupun seterusnya.

2) Demikian juga halnya dengan kelompok lain, akan diberi penomoran oleh guru, sehingga semua anggota tim yang memperoleh nomor 1 , akan bermain di meja turnamen 1, dan seterusnya.

3) Setiap meja turnamen terdiri dari 10 orang yang merupakan wakil dari masing-masing kelompok. Dalam setiap meja permainan tidak diperbolehkan adanya peserta yang berasal dari kelompok yang sama.

4) Setiap pemain dalam tiap meja terlebih dulu menentukan pembaca soal, penulis skor dan pemain yang pertama yang akan menjawab soal dengan cara di undi. Pemenangnya kemudian dapat mengambil kartu berisi nomor soal yang selanjutnya 


\section{Educatio: Jurnal IImu Kependidikan}

Vol. 16, NNo 1 Juli 2021, hal. 24-36

http://e-journal.hamzanwadi.ac.id/index.php/edc

e-ISSN: 2527-9998

DOI: 10.29408/edc.v16i1.2831

diberikan kepada pembaca soal. Pembaca soal akan membacakan soal sesuai dengan nomor undian yang telah didapatkan pemain. Soal-soal tersebut akan dikerjakan secara mandiri oleh pemain dan penantang selama waktu yang telah ditentukan.

5) Apabila waktu habis, pemain membacakan hasil pekerjaannya kemudian ditanggapi oleh penantang, Ketika pembaca soal membuka kunci jawaban, skor hanya akan diberikan kepada pemain atau penantang yang lebih dulu menjawab dengan benar.

6) Ketika seluru pemain memiliki jawaban yang salah, maka otomatis permainan dilanjutkan pada kartu soal berikutnya. Posisi pemain diputar searah dengan jarum jam agar semua peserta masing-masing dapat berperan sebagai pembaca soal, penulis nilai, pemain, dan penantang. (Setiap peserta harus mempunyai kesempatan yang sama untuk berperan sebagai pemain, penulis nilai, penantang, dan pembaca soal).

7) Setelah semua selesai terjawab, setiap pemain menghitung total skor yang diperoleh

8) Selanjutnya setiap pemain kembali kepada kelompok asal.

9) Setelah pertandingan berakhir, dilakukan penghitungan skor kelompok untuk memberikan penghargaan kepada kelompok yang memperoleh skor tertinggi. Adapun penghargaan kelompok diberikan sesuai dengan criteria pada tabel berikut ini:

Tabel 1. Kriteria Penghargaan Kelompok

\begin{tabular}{|c|l|}
\hline Nilai Kelompok & \multicolumn{1}{|c|}{ Predikat } \\
\hline 30 sampai 49 & Tim Cukup \\
\hline 50 sampai 60 & Tim Baik \\
\hline 61 ke atas & Tim Baik Sekali \\
\hline
\end{tabular}

\section{c. Pengamatan}

Pelaksanaan pengamatan proses pembelajaran pada siklus ini, sebagian besar siswa sangat antusias mengikuti pembelajaran, hal ini terlihat dari banyaknya siswa yang menanggapi setiap pertanyaan yang diajukan oleh guru mengenai materi yang diajarkan yaitu materi Dasar-dasar Pertidaksamaan. Hal lain yang membuat siswa antusias, dari pemberitahuan sebelumnya bahwa nantinya dalam pembelajaran akan ada kegiatan permainan.

Namun dibalik antusias para siswa tersebut, terdapat kekurangan yaitu kerja sama dari setiap anggota kelompok yang kurang baik, meskipun dalam kegiatan pertandingan (tournament) siswa terlihat lebih aktif dan antusias dalam menjawab pertanyaan. Kemudian dalam kegiatan ini terlihat siswa kurang tertib, hal ini dikarenakan banyaknya siswa yang kurang memahami langkah-langkah dan aturan pertandingan. Hasil evaluasi yang diperoleh setelah pelaksanan model pembelajaran TGT ini menunjukkan nilai rata-rata kelas 65,40.

d. Refleksi

Dari hasil pengamatan diskusi kelompok terlihat kurangnya kerja sama dari setiap anggota kelompok, peneliti dan guru observer menyimpulkan hal ini dikarenakan adanya beberapa anggota yang kurang bersemangat dalam kegiatan pembelajaran yang ditunjukkan oleh hasil angket motivasi belajar. 


\section{Educatio: Jurnal IImu Kependidikan}

Vol. 16, NNo 1 Juli 2021, hal. 24-36

http://e-journal.hamzanwadi.ac.id/index.php/edc

e-ISSN: 2527-9998

DOI: 10.29408/edc.v16i1.2831

Hasil angket motivasi belajar siswa pada siklus I menunjukkan adanya motivasi siswa dengan kriteria sangat baik sebesar 9,20\%, kriteria baik sebesar 30,30\%, kriteria cukup baik sebesar 35,50 \% dan kriteria kurang baik $25 \%$. Hal ini menunjukkan sebanyak $75 \%$ siswa di kelas XI IPS 1 mempunyai motivasi yang baik meskipun terdapat motivasi dengan nilai kurang baik sebanyak $25 \%$.

Dari hasil pengamatan ini, terlihat beberapa siswa masih belum memahami peraturan dan langkah-langkah permainan, oleh sebab itulah pada siklus II guru akan memberi penjelasan secara lebih rinci mengenai langkah-langkah permainannya. Selanjutnya, guru akan lebih berperan sebagai motivator dalam diskusi kelompok maupun dalam kegiatan permainan. Dari hasil evaluasi menunjukkan hasil rata-rata kelas 65,40, ini berarti sudah memenuhi kriteria ketuntasan belajar yang ditetapkan oleh guru mata pelajaran yaitu sebesar 63,00 .

\section{Siklus II}

Kegiatan pembelajaran pada siklus II dilaksanakan 1 kali pertemuan dan setiap pertemuan belangsung selama 2 jam pelajaran ( 2 x 45 menit).

a. Perencanaan dan Persiapan Tindakan

Perencanaan dan persiapan tindakan yang akan dilakukan meliputi:

1) Penyusunan Rencana Pelaksanaan Pembelajaran (RPP) dengan revisi berdasarkan refleksi pada siklus I pada materi Pertidaksamaan Linear Dua Variabel.

2) Menyiapkan langkah-langkah pada model pembelajaran TGT

3) Menyiapkan lembar observasi pembelajaran

4) Menyiapkan LKS

5) Menyiapkan kartu soal untuk tournamen

6) Menyiapkan blangko nilai pada setiap meja kelompok dan blangko nilai kelompok.

b. Pelaksanaan Tindakan

Kegiatan pembelajaran pada siklus 1 ini dilaksanakan satu kali pertemuan dengan langkahlangkah yaitu:

1) Guru memberikan penjelasan mengenai materi Menggambarkan Pertidaksamaan Linear Dua Variabel.

2) Siswa membentuk kelompok-kelompok belajar kemudian melakukan diskusi

3) Memulai permainan (game tournament)

4) Penghargaan kepada kelompok yang memperoleh skor tertinggi

Pada tahap ini, kegiatan pembelajaran dimulai dengan menjelaskan materi Menggambarkan Pertidaksamaan Linear Dua Variabel dengan demonstrasi dan metode tanya jawab. Pada akhir penjelasan, guru memberikan kesempatan kepada siswa untuk menyampaikan pertanyaan mengenai materi yang belum dipahami sebelum kegiatan diskusi kelompok dilaksanakan. 


\section{Educatio: Jurnal IImu Kependidikan}

Vol. 16, NNo 1 Juli 2021, hal. 24-36

http://e-journal.hamzanwadi.ac.id/index.php/edc

e-ISSN: 2527-9998

DOI: 10.29408/edc.v16i1.2831

Setelah pemberian materi selesai, siswa dikelompokan menjadi 10 (sepuluh) kelompok baru yang dibentuk berdasarkan tes formatif setelah siklus I dilaksanakan dengan masing-masing kelompok beranggotakan maksimal 4 (empat) orang. Kemudian guru membagikan LKS materi mengenai Menggambarkan Pertidaksamaan Linear Dua Variabel untuk didiskusikan setiap kelompok.

Setelah diskusi kelompok selesai dilakukan, kemudian pertandingan (tournament) dimulai dengan langkah-langkah dan aturan sebagai berikut:

1) Setiap anggota kelompok akan mendapatkan penomoran 1, 2, 3, 4, yang dipasang di dada masing-masing siswa. Penomoran ini yang kemudian digunakan sebagai acuan untuk menentukan anggota tim tersebut akan bermain pada meja turnamen ke berapa. Misalnya pada kelompok A, salah satu anggota yang bernama Rizal diberi nomor 1 oleh guru, ini berarti Agus akan bermain pada meja turnamen 1, begitupun seterusnya.

2) Demikian sama halnya dengan kelopok lain, akan diberikan penomoran oleh guru, sehingga semua anggota tim yang memperoleh nomor 1, akan bermain di meja turnamen 1, dan seterusnya.

3) Setiap meja turnamen terdiri dari 10 orang yang merupakan wakil dari masingmasing kelompok asal. Dalam setiap meja permainan tidak boleh ada peserta yang berasal dari kelompok yang sama.

4) Setiap pemain dalam tiap meja terlebih dulu menentukan pembaca soal, penulis skor dan pemain yang pertama yang akan menjawab soal dengan cara di undi. Pemenangnya kemudian dapat mengambil kartu berisi nomor soal yang selanjutnya diberikan kepada pembaca soal. Pembaca soal akan membacakan soal sesuai dengan nomor undian yang telah didapatkan pemain. Soal-soal tersebut akan dikerjakan secara mandiri oleh pemain dan penantang selama waktu yang telah ditentukan.

5) Apabila waktu habis, pemain membacakan hasil pekerjaannya kemudian ditanggapi oleh penantang, Ketika pembaca soal membuka kunci jawaban, skor hanya akan diberikan kepada pemain atau penantang yang lebih dulu menjawab dengan benar.

6) Ketika seluruh pemain memiliki jawaban yang salah, maka otomatis permainan dilanjutkan pada kartu soal berikutnya. Posisi pemain diputar searah dengan jarum jam agar semua peserta masing-masing dapat berperan sebagai pembaca soal, penulis nilai, pemain, dan penantang. (Setiap peserta harus mempunyai kesempatan yang sama untuk berperan sebagai pemain, penulis nilai, penantang, dan pembaca soal).

7) Setelah semua kartu selesai terjawab, setiap pemain mulai menghitung kartu yang diperoleh kemudian menentukan skor berdasarkan tabel yang telah disediakan.

8) Setelah selesai, setiap pemain kembali kepada kelompok asalnya.

9) Setelah pertandingan berakhir, maka akan dilakukan penghitungan skor kelompok untuk memberikan penghargaan kepada kelompok yang memiliki skor tertinggi.

c. Pengamatan 


\section{Educatio: Jurnal IImu Kependidikan}

Vol. 16, NNo 1 Jufi 2021, hal. 24-36

http://e-journal.hamzanwadi.ac.id/index.php/edc

e-ISSN: 2527-9998

DOI: 10.29408/edc.v16i1.2831

Pelaksanaan pengamatan proses pembelajaran pada siklus ini, sebagian besar siswa antusias mengikuti pembelajaran, hal ini terlihat dari banyaknya siswa yang menanggapi setiap pertanyaan yang berikan oleh guru mengenai materi yang diajarkan yaitu materi Menggambarkan Pertidaksamaan Linear Dua Variabel.

Dalam diskusi kelompok pada siklus II terlihat setiap kelompok lebih aktif bekerjasama dibandingkan dengan siklus I. Dalam kegiatan pertandingan (tournament) siswa terlihat aktif dan antusias dalam menjawab setiap pertanyaan. Setiap anggota dari masing-masing kelompok sudah memahami betul peraturan dari permainannya, hal ini dibuktikan kegiatan permainan yang berjalan lancar.

Pada akhir siklus II guru membagikan angket kepada siswa untuk diisi, hal ini bertujuan agar guru dapat mengetahui besarnya motivasi belajar siswa terhadap tindakan yang telah diberikan. Hasil evaluasi yang diperoleh setelah pelaksanan model pembelajaran TGT ini menunjukkan hasil rata-rata kelas 68,00.

d. Refleksi

Berdasarkan hasil pengamatan dalam pelaksanaan model pembelajaran TGT, sebagian besar siswa sudah mampu mengikuti jalannya permainan dengan baik. Hal ini dapat dilihat dari jalannya permainan yang tertib sesuai aturan yang ada. Pertanyaan-pertanyaan yang diberikan oleh guru juga mampu di jawab dengan baik oleh sebagian besar siswa. Antusias dan kerjasama yang baik mulai terbangun pada siklus II.

Hasil angket motivasi belajar siswa pada siklus II menunjukkan adanya motivasi siswa dengan kriteria sangat baik sebesar $14,40 \%$, kriteria baik sebesar 35,30\%, kriteria cukup baik sebesar 30,30 \% dan kriteria kurang baik $20 \%$. Hal ini menunjukkan sebanyak $80 \%$ siswa di kelas XI IPS 1 mempunyai motivasi meskipun motivasi yang paling rendah hanya cukup baik. Dari hasil evaluasi yang menunjukkan hasil rata-rata kelas 68,00, ini berarti sudah memenuhi kriteria ketuntasan belajar yang ditetapkan oleh guru mata pelajaran sebesar 63,00.

\section{Siklus III}

Kegiatan pembelajaran siklus III dilaksanakan 1 kali pertemuan selama 2 jam pelajaran (2 x 45 menit).

a. Perencanaan dan Persiapan Tindakan

Perencanaan dan persiapan tindakan yang dilakukan peneliti meliputi :

1) Penyusunan Rencana Pelaksanaan Pembelajaran (RPP) dengan revisi sesuai refleksi siklus II pada materi tentang Pertidaksamaan Linear Dua Variabel.

2) Menyiapkan langkah-langkah pada model pembelajaran TGT

3) Menyiapkan lembar observasi pembelajaran

4) Menyiapkan LKS

5) Menyiapkan kartu soal untuk tournamen

6) Menyiapkan blangko nilai pada setiap meja kelompok dan blangko nilai kelompok. 


\section{Educatio: Jurnal IImu Kependidikan}

Vol. 16, NNo 1 Juli 2021, hal. 24-36

http://e-journal.hamzanwadi.ac.id/index.php/edc

e-ISSN: 2527-9998

DOI: 10.29408/edc.v16i1.2831

\section{b. Pelaksanaan Tindakan}

Kegiatan pembelajaran pada siklus III dilaksanakan satu kali pertemuan dengan langkah berikut :

1) Guru memberikan penjelasan mengenai materi Daerah Penyelesaian Pertidaksamaan Linear Dua Variabel

2) Siswa membentuk kelompok-kelompok belajar kemudian melakukan diskusi

3) Memulai permainan (game tournament)

4) Penghargaan kepada kelompok yang memperoleh skor tertinggi

Pada tahap ini, kegiatan pembelajaran dimulai dengan memaparkan materi mengenai Daerah Penyelesaian Pertidaksamaan Linear Dua Variabel dengan metode demonstrasi dan tanya jawab. Pada akhir penjelasan guru memberikan kesempatan kepada siswa untuk mengajukan pertanyaan tentang materi yang belum dipahami sebelum kegiatan diskusi kelompok dilaksanakan. Setelah pemberian materi, siswa dibagi menjadi 10 (sepuluh) kelompok seperti pada siklus I dan II. Kemudian guru membagikan LKS materi Menentukan Daerah Penyelesaian Pertidaksamaan Linear Dua Variabel untuk didiskusikan oleh setiap kelompok.

Setelah diskusi kelompok selesai maka dilaksanakanlah pertandingan (tournament) dengan langkah-langkah dan aturan yang sama seperti pada siklus I maupun II. Setelah pertandingan berakhir, kemudian dilakukan penghitungan skor untuk memberikan penghargaan kepada kelompok dengan skor tertinggi. Adapun penghargaan akan diberikan kepada kelompok dengan skor tertinggi berdasarkan kriteria seperti pada tabel 2.

\section{c. Pengamatan}

Pelaksanaan pengamatan proses pembelajaran pada siklus ini, sebagian siswa mengalami kesulitan dalam memahami materi yang diajarkan yaitu Menentukan Dareah Penyelesaian Pertidaksamaan Linear Dua Variabel, hal ini terlihat dari banyaknya siswa yang bertanya mengenai cara pengerjaan soal yang diberikan oleh guru dalam diskusi kelompok.

Pada akhir siklus III, guru membagikan angket kepada siswa untuk melihat motivasi belajar siswa terhadap tindakan yang diberikan. Hasil evaluasi yang diperoleh yaitu setelah pelaksanan model pembelajaran TGT ini diperoleh hasil rata-rata kelas sebesar 69,00.

d. Refleksi

Hasil angket motivasi belajar siswa pada siklus III menunjukkan adanya motivasi siswa dengan kriteria sangat baik sebesar $13,10 \%$, kriteria baik sebesar 40,40\%, kriteria cukup baik sebesar 36,50 \% dan kriteria kurang baik $10 \%$. Hal ini menunjukkan sebanyak $90 \%$ siswa di kelas XI IPS 1 mempunyai motivasi meskipun motivasi yang paling rendah hanya cukup baik. 
Educatio: Jurnal IImu Kependidikan

Vol. 16, JNo 1 Juli 2021, hal. 24-36

http://e-journal.hamzanwadi.ac.id/index.php/edc

e-ISSN: 2527-9998

DOI: 10.29408/edc.v16i1.2831

Dari hasil evaluasi menunjukkan hasil rata-rata kelas 69,00, artinya kriteria ketuntasan belajar yang ditetapkan oleh guru mata pelajaran sebesar 63,00 sudah terpenuhi.

\section{Pelaksanaan Kegiatan:}

Pelaksanaan tindakan meliputi beberapa hal yaitu :

1. Pembuatan kelompok-kelompok belajar yang terdiri dari maksimal empat orang siswa dengan kemampuan, ras, suku, jenis kelamin dan usia yang berbeda (heterogen). Untuk lebih jelasnya dapat dilihat pada Gambar 1

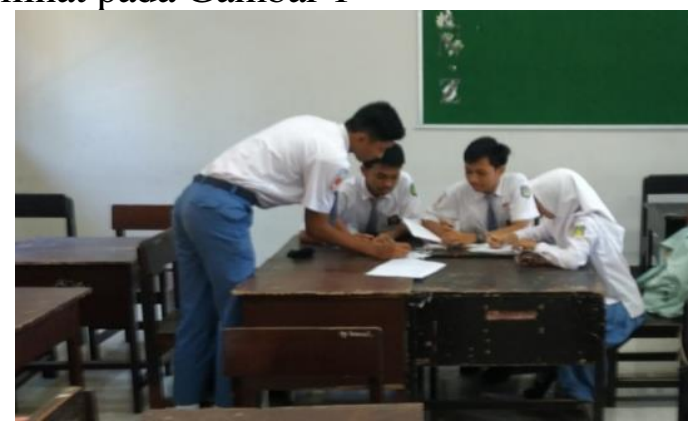

Gambar 1 Pembuatan kelompok yg terdiri dari 4 orang siswa

2. Membagi petunjuk kegiatan atau aturan permainan yang telah dibuat pada tiap-tiap kelompok. Untuk lebih jelasnya dapat dilihat pada Gambar 2

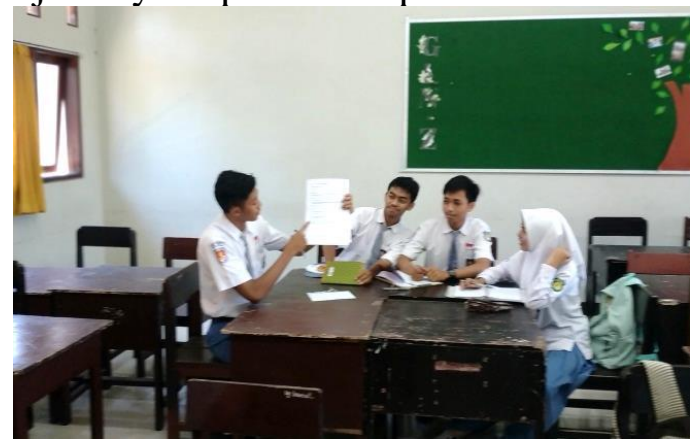

Gambar 2 Membagi petunjuk kegiatan atau aturan permainan

3. Siswa melaksanakan model pembelajaran tersebut sesuai dengan petunjuk kegiatan yang telah dibuat oleh guru mata pelajaran. Untuk lebih jelasnya dapat dilihat pada Gambar 3 
Educatio: Jurnal IImu Kependidikan

Vol. 16, No 1 Juli 2021, hal. 24-36

http://e-journal.hamzanwadi.ac.id/index.php/edc

e-ISSN: 2527-9998

DOI: 10.29408/edc.v16i1.2831

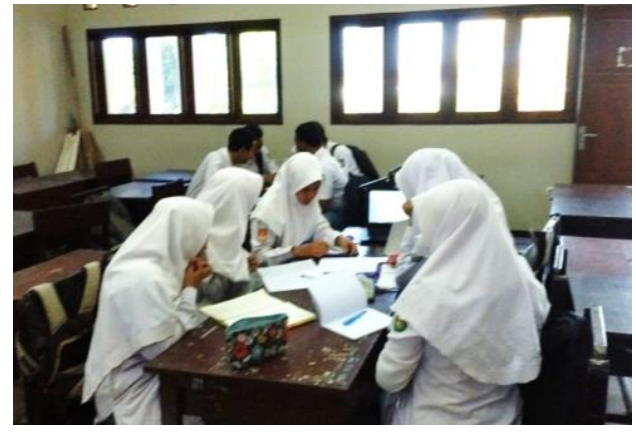

Gambar 3 Siswa melaksanakan permainan sesuai petunjuk kegiatan

4. Masing-masing anggota kelompok berkompetisi untuk mendapatkan nilai tertinggi. Untuk lebih jelasnya dapat dilihat pada Gambar 4 dan gambar 5

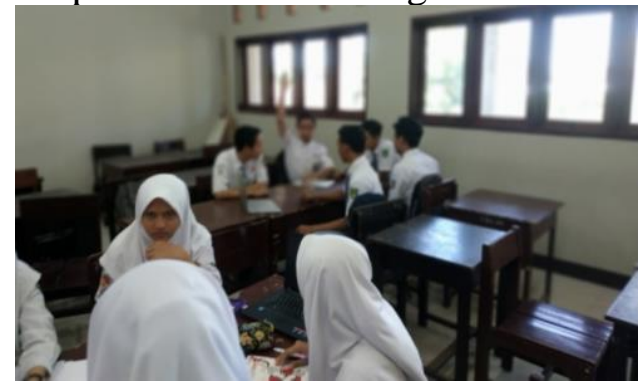

Gambar 4 Siswa berkompetisi dengan menjawab pertanyaan yg ada

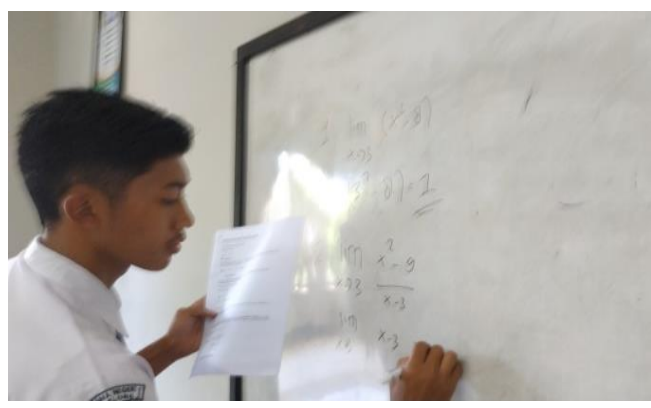

Gambar 5 Siswa yg maju menjawab soal dengan benar akan mendapatkan nilai

\section{Pembahasan}

1. Penerapan model pembelajaran kooperatif tipe TGT mampu meningkatkan motivasi belajar siswa: berdasarkan hasil dari penyebaran angket motivasi belajar siswa secara umum dihitung jumlah rata-rata setiap aspek yang diukur mengalami kenaikan dari 75 $\%$ menjadi $80 \%$ kemudian meningkat menjadi $90 \%$ yang terdiri dari beberapa kategori motivasi seperti sangat baik, baik dan cukup baik.

2. Permainan dalam TGT ini dapat meningkatkan antusias dan semangat siswa: pada saat permainan berjalan, para pemain pada setiap meja turnamen yang merupakan wakil dari kelompok asalnya terlihat bersemangat untuk menjawab pertanyaan yang dibacakan, 


\section{Educatio: Jurnal IImu Kependidikan}

Vol. 16, NNo 1 Juli 2021, hal. 24-36

http://e-journal.hamzanwadi.ac.id/index.php/edc

e-ISSN: 2527-9998

DOI: 10.29408/edc.v16i1.2831

bahkan sebelum pemain yang memiliki giliran untuk menjawab, ada penantang yang segera ingin menjawab pertanyaan terlebih dulu.

3. Penerapan model pembelajaran kooperatif tipe TGT dapat memberikan peningkatan hasil belajar siswa pada pelajaran Matematika, bila diperhatikan, nilai rata-rata siswa setiap siklus mengalami kenaikan. Pada siklus I dengan materi Dasar-dasar Pertidaksamaan rata-rata hasil nilai siswa 65,40. Pada siklus II dengan materi Menggambarkan Pertidaksamaan Linear Dua Variabel rata-rata hasil nilai siswa 68,00. Pada siklus III dengan materi Daerah Penyelesaian Pertidaksamaan Linear Dua Variabel rata-rata hasil nilai siswa 69,00 .

\section{SIMPULAN}

Motivasi belajar siswa pada pelajaran Matematika secara umum mengalami kenaikan rata-rata motivasi minimal cukup baik yang awalnya sebesar $75 \%$ siswa menjadi sebesar $80 \%$ siswa kemudian meningkat lagi menjadi $90 \%$ siswa di kelas XI IPS 1 . Hal ini menurut analisis peneliti disebabkan oleh : (1) Siswa lebih tertarik dengan variasi model pembelajaran yang menurut mereka baru dan belum pernah didapatkan sebelumnya, (2) Materi pembelajaran yang dibahas relatif dapat dipahami oleh siswa karena cara penyampaiannya yang uni yaitu melalui permainan. Hasil tes yang dilaksanakan pada setiap siklus mengalami kenaikan, mulai dari siklus I, II dan siklus III. Pada siklus I nilai rata-rata sebesar 65,40, pada siklus II nilai rata-rata sebesar 68,00 dan pada siklus III nilai rata-rata sebesar 69,00

\section{PERNYATAAN PENULIS}

Penulis menyatakan bahwa artikel ini belum pernah diterbitkan dalam jurnal manapun

\section{DAFTAR PUSTAKA}

Erlinda, N. (2017). Peningkatan aktivitas dan hasil belajar siswa melalui model kooperatif tipe team game tournament pada mata pelajaran fisika di SMK. Tadris: Jurnal Keguruan Dan Ilmu Tarbiyah, 2(1), 47-52.

Kholiso, Y. N. (2017). Perbedaan Penerapan Model Pembelajaran TGT-Problem Posing dan Jigsaw Terhadap Minat dan Hasil Belajar. Edumatic: Jurnal Pendidikan Informatika, 1(2), 49-54.

Kuswanto, H., Rodiyanti, N., Kholisho, Y. N., \& Arianti, B. D. D. (2020). Pengaruh Kemampuan Matematika Terhadap Kemampuan Computational Thinking Pada Anak Usia Sekolah Dasar. Educatio, 15(2), 138-144.

Ruswandi,Ruswandi,dkk.(2010).Metode penelitian Pendidikan SD.Bandung:Upi Press.

Slavin. E. R.( 2005). Cooperative learning teori, riset dan praktik. Penerjemah: Narulita Yusron.Bandung: Nusamedia.

Winkel, W.S. (1991). Psikologi Pendidikan dan Evaluasi Belajar. Jakarta. PT. Gramedia 